\title{
Transitional geometries between gently plunging and steeply plunging folds: an example from the Lower Palaeozoic Brabant Massif, Anglo-Brabant deformation belt, Belgium
}

\author{
T. N. DEBACKER ${ }^{1}$, M. SINTUBIN ${ }^{1} \&$ J. VERNIERS ${ }^{2}$ \\ ${ }^{1}$ Structural Geology and Tectonics Group, Katholieke Universiteit Leuven, Redingenstraat 16, B-3000 Leuven, Belgium \\ (e-mail: timothy.debacker@geo.kuleuven.ac.be) \\ ${ }^{2}$ Laboratory of Palaeontology, Universiteit Gent, Krijgslaan 281, S8, B-9000 Gent, Belgium
}

\begin{abstract}
Although many studies have dealt with markedly different fold orientations and associated cleavage-fold relationships within individual, single-phase deformed fold belts, there are very few descriptions of possible gradual, transitional fold geometries. The Lower Cambrian steep core of the singlephase deformed Brabant Massif contains steeply plunging, west-facing folds with a Z-shaped asymmetry, whereas the Ordovician-Silurian southern rim consists of gently plunging, upward facing folds. A gradual transition is observed between these end-member orientations, in a NW-SE-trending zone $1-1.5 \mathrm{~km}$ wide, in which the folds appear to be strongly curvilinear and locally downward facing. The structural geometries within this transition zone are described in detail and the geometric changes analysed in the light of the fold transition. The strongly variable fold orientations are tentatively attributed to a bulk oblate tectonic strain. The transition zone overlies an aeromagnetic lineament, classically interpreted as a dextral shear zone. The steeply plunging folds, the transition zone and the aeromagnetic lineaments are all attributed to a local dextral transpression, in which deformation is partitioned both vertically and laterally. The results indicate that within zones of heterogeneous transpression, the different deformation domains are not necessarily always fault bounded.
\end{abstract}

Keywords: Brabant Massif, magnetic anomalies, folds, strain, transpression.

Many fold belts contain folds with variable orientations. The presence of markedly different tectonic fold orientations and associated cleavage-fold relationships within individual fold belts can essentially be attributed to two main causes: (1) fold interference patterns resulting from a polyphase deformation or (2) strain partitioning or localization during a single-phase deformation. The latter is characteristic for shear zones (Ramsay \& Graham 1970) and frequently occurs within transpression zones (Jones \& Tanner 1995; Jones et al. 1997; Tikoff \& Greene 1997; Dewey et al. 1998).

Many studies have dealt at length with fold interference patterns resulting from polyphase deformation (e.g. Reynolds \& Holmes 1954; Ramsay 1958, 1962) and with the different fold geometries related to shear zones (e.g. Cobbold \& Quinquis 1980; Coward \& Potts 1983; Park 1988; Skjernaa 1989; Fossen \& Rykkelid 1990; Alsop \& Holdsworth 1993, 1999, 2002; Mies 1993; Debacker 1999). Also, the fold geometries encountered within the different domains of transpression zones have been the focus of several studies (e.g. Holdsworth 1989; Holdsworth \& Pinheiro 2000; Holdsworth et al. 2002a, b). However, most studies remain rather vague on the subject of the actual transition between the different fold geometries. In particular, within nonhomogeneous transpression zones, characterized by a partitioning of deformation into different deformation domains (Jones \& Tanner 1995), the folds and the cleavage-fold relationships encountered within the different domains and often used to characterize these domains are rigorously described, but apparently the limits between the domains are either taken to coincide with important faults or shear zones, or are not described (e.g. Holdsworth et al. 2002a, b). This may give the impression that within such zones strain is so strongly partitioned that the transition between the domains is always abrupt. However, as pointed out by Jones \& Tanner (1995), simple, homogeneous transpression (see Harland 1971; Sanderson \& Marchini 1984), on the one hand, in which the pure shear and simple shear components are both uniformly distributed across the deformation zones, and heterogeneous transpression, on the other hand, with a complete separation of the pure shear and simple shear components into separate deformation domains, can be considered as two end-members of transpression. Hence, the separation into well-defined and outlined domains with particular deformation geometries, separated by abrupt structural discontinuities, is not a necessity. Gradual transitions between the domains and related fold geometries may be more common than the literature would suggest. This paper documents such a gradual transition within the single-phase deformed, Lower Palaeozoic Brabant Massif, Belgium.

\section{Geological setting}

The largely concealed Lower Palaeozoic Brabant Massif (Fig. 1) forms the southeastern part of the Anglo-Brabant deformation belt, one of the fold belts of eastern Avalonia (Van Grootel et al. 1997; Verniers et al. 2002). The massif comprises low-grade, mainly fine-grained, siliciclastic deposits, ranging from the earliest Cambrian to the late Silurian in age. An angular unconformity separates these deformed, low-grade Lower Palaeozoic deposits from overlying, diagenetic, undeformed Givetian deposits (Legrand 1967; De Vos et al. 1993b; Van Grootel et al. 1997; Debacker et al. 1999). At present, there is evidence only for a single progressive deformation event, currently considered to have taken place between the Llandovery and the end of the 


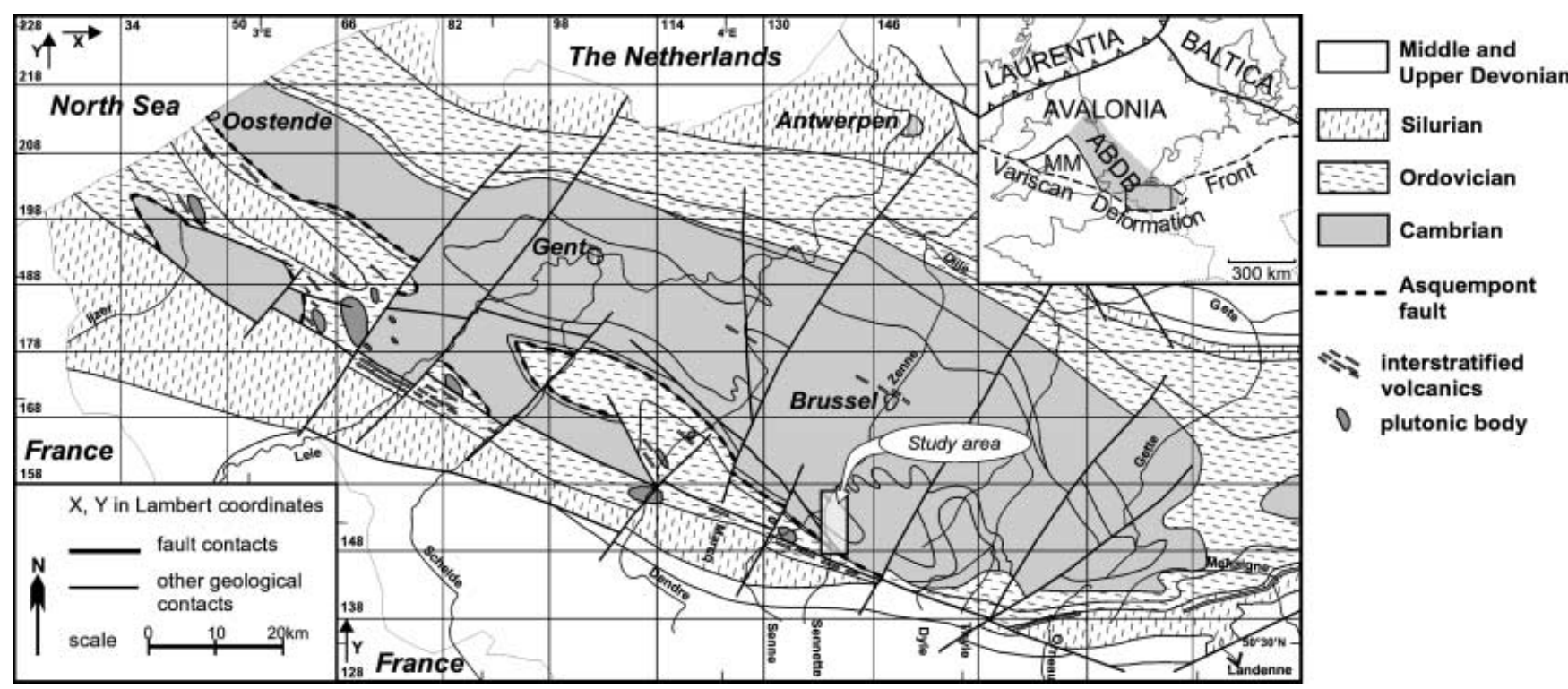

Fig. 1. Geological subcrop map of the Brabant Massif (after De Vos et al. 1993b; Van Grootel et al. 1997) showing the position of the study area (see Fig. 2). The trace of the Asquempont fault is taken from Debacker (2001). The inset (upper right) shows the position of the Brabant Massif within the Anglo-Brabant deformation belt (ABDB) along the NE side of the Midlands Microcraton (MM) in the context of Avalonia, Baltica and Laurentia.

Early Devonian, possibly continuing into the Eifelian (Debacker 2001; Debacker et al. 2002; Verniers et al. 2002). The main features associated with this deformation are folds with a welldeveloped, cogenetic cleavage (Sintubin 1997a, 1999; Debacker 2001; Debacker et al. 2002; Verniers et al. 2002).

Apparently a division in fold style exists between the Ordovician-Silurian southern part and the Lower Cambrian core of the massif (Sintubin 1997a, 1999; Sintubin et al. 1998; Debacker 2001). In the Ordovician-Silurian outcrop areas, subhorizontal to gently plunging folds occur (Malaise 1873; Fourmarier 1914, 1921; Mortelmans 1953; Legrand 1967; Sintubin 1997a, 1999; Debacker 1999, 2001, 2002; Debacker et al. 1999, 2001, 2003; Belmans 2000). In contrast, the poorly exposed Lower Cambrian core of the massif appears to be characterized by an overall steepness of bedding and cleavage, with steeply plunging to reclined folds (Fourmarier 1921; Vander Auwera 1983; Sintubin 1997a, 1999; Sintubin et al. 1998).

Prior to this study, the transition between the two fold styles has never been observed, although some workers have made suggestions on its position and nature. On the basis of aeromagnetic data, and the original description by Legrand (1967) of the Asquempont fault, Sintubin $(1997 b, 1999)$ and Sintubin et al. (1998) suggested that the Asquempont fault in the Sennette valley (Fig. 1, F8 in Fig. 2) forms the limit between the fold styles. However, a recent re-examination of this fault shows that it is a pre-cleavage extensional detachment that is unrelated to the fold transition (Debacker et al. 2003).

To fully explain the nature of the fold transition, both the gently and the steeply plunging folds will be described first, based on observations in the Sennette valley. The description of fold orientations is based on the study by Fleuty (1964). Tables with orientation data can be obtained from the Society Library or the British Library Document Supply Centre, Boston Spa, Wetherby, West Yorkshire LS23 7BQ, UK as Supplementary Publication No. SUP18199 (7 pages). It is also available online at http://www.geolsoc.org.uk/SUP18199.

\section{Two main fold types within the Brabant Massif}

\section{Subhorizontal to gently plunging folds}

In the predominantly fine-grained Silurian and Ordovician formations in the southern part of the Brabant Massif subhorizontal to gently plunging, moderately to steeply inclined, occasionally upright, gentle to closed folds occur, with rounded to sub-angular hinges (Fig. 3a). The folds commonly have a stepfold-like geometry with a SW-verging asymmetry. The largest folds have wavelengths of $2-4 \mathrm{~km}$. Decametre- to metre-scale folds, observable in individual outcrops, generally seem restricted to the hinge zones of the large stepfolds (Debacker et al. 1999, 2001; Debacker 2001; Van Grootel et al. 2002). Cleavage-fold relationships (e.g. cleavage fanning, cleavage refraction) point to a cogenetic relationship between folding and cleavage development (Sintubin 1997a, 1999; Debacker et al. 1999, 2001; Debacker 2001). A small-angle axial cleavage transection (sensu Johnson 1991) is common (Sintubin 1997a, 1999), the sense of which may change from fold to fold (Debacker et al. 1999, 2003; Debacker 2001). The variable amount and sense of cleavage transection, in combination with the slight variations in fold plunge and plunge direction, can be attributed to a periclinal fold shape (see Debacker et al. 1999). Although there is no evidence for a regionally consistent sense of cleavage transection (Debacker 2001), the sum of the cleavage and bedding data from the Sennette valley suggests a bulk axial cleavage transection of $7^{\circ}$ anticlockwise (Fig. 3a).

\section{Steeply plunging to reclined folds}

This fold type has been described by Sintubin et al. (1998) along a discontinuous temporary outcrop section of $1.15 \mathrm{~km}$ length in Lower Cambrian turbidites of the Tubize Formation at Lembeek (outcrops Lembeek 1-7 in Fig. 2). The folds plunge steeply to the NW, have straight limbs, a Z-shaped geometry, steeply northdipping, east-west-trending axial surfaces, open interlimb an- 


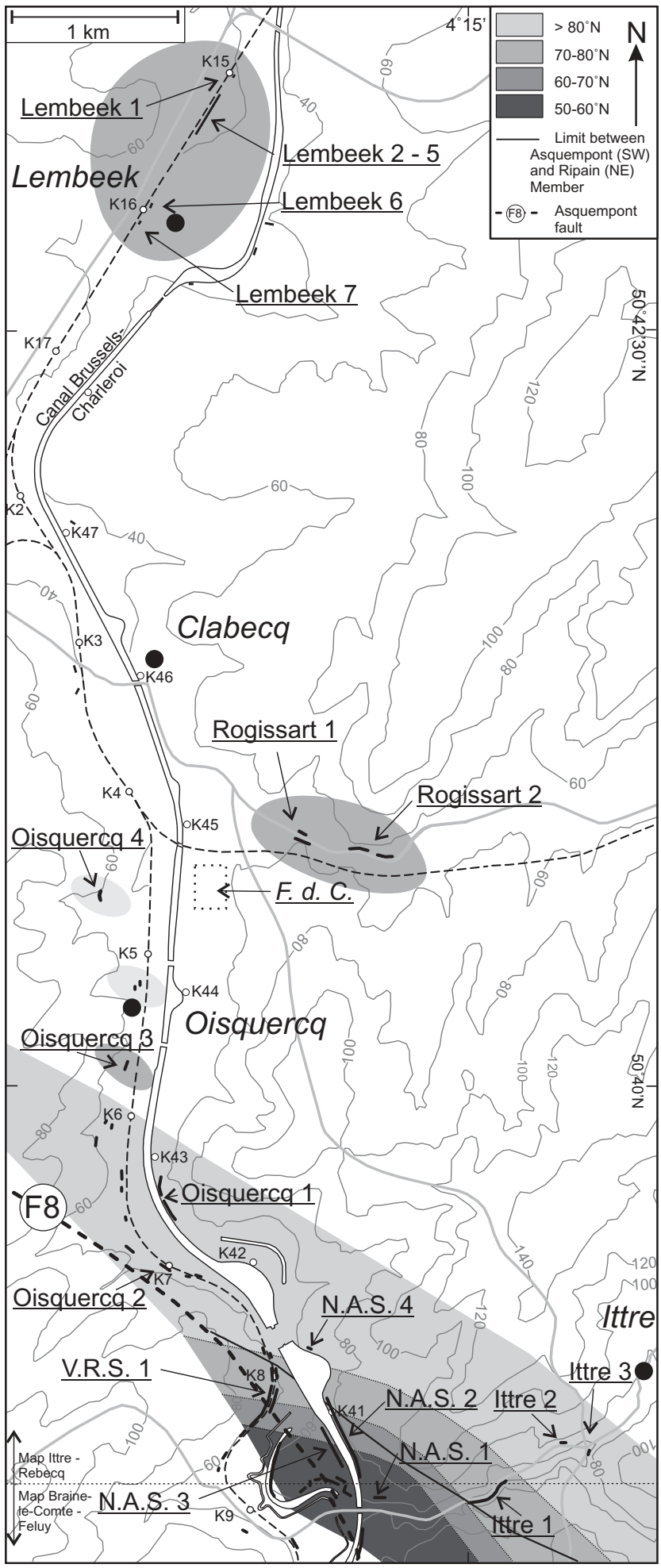

Fig. 2. Simplified map of the study area in the Sennette valley, along the Brussels-Charleroi canal, showing the outcrop positions (in black and labelled; N.A.S., Northern Asquempont section; V.R.S., Virginal Railway section; F.d.C., Forges de Clabecq), the trace of the Asquempont fault (F8; Debacker et al. 2003), the limit between the Asquempont Member and the Ripain Member, and, in grey shades, the mean cleavage dips. (See Fig. 1 for position within the Brabant Massif.) gles, sub-angular hinges and wavelengths between 100 and $150 \mathrm{~m}$ (Fig. 3b). The fold facing direction (younging direction) is towards the west. The cleavage shows a pronounced divergent cleavage fanning. In the long, subvertical, NW-SE-trending limbs (type 1 limbs) the cleavage is subvertical to steeply NNEdipping, whereas in the shorter, steeply NW-dipping, NE-SWtrending limbs (type 2 limbs) the cleavage dips steeply towards the NNW. In both limbs the average angle between cleavage and bedding is about $20^{\circ}$. The cleavage-fold relationship points to a cogenetic development of cleavage and folding. The divergent cleavage fanning is attributed to flexural folding (Sintubin et al. 1998), compatible with the presence of subhorizontal striations on the fold limbs and with the geometry of small-scale folds in the hinge zones.

At Rogissart (outcrops Rogissart 1-2 in Fig. 2), steeply ENEdipping, WSW-younging beds of the Tubize Formation occur, affected by a steeply NE-dipping cleavage, trending $c .25^{\circ}$ anticlockwise to bedding. The cleavage-bedding intersection and the inferred cleavage fan axis and fold axis plunge steeply towards the NE (Fig. 3c). This cleavage-bedding disposition is practically identical to that of the type 1 limbs of the Lembeek folds (see Fig. 3b). Hence, it seems that the Rogissart section contains a uniformly dipping type 1 limb of a steeply plunging, west-facing fold. The large thickness of this type 1 limb, minimum $500 \mathrm{~m}$, is compatible with the Z-shaped fold geometry observed at Lembeek.

\section{Characterization of the transition zone: the Ittre- Oisquercq-Asquempont area}

\section{Lithology}

The Ittre-Oisquercq-Asquempont area (Fig. 2) comprises two lithological units, both belonging to the lower Middle Cambrian Oisquercq Formation. The upper unit consists of greenish grey, porous mudstones of the Asquempont Member, the lower unit of dark, purplish grey to blue claystones and mudstones of the Ripain Member (Verniers et al. 2001). A gradual transition occurs between the two members, in a zone c. $10 \mathrm{~m}$ wide (Fig. 2; Debacker 2001; see Legros 1991). Both members are characterized by an extreme lithological homogeneity. To the authors' knowledge, prior to this study only a few bedding planes were ever observed in the Oisquercq Formation in the Asquempont area (outcrop N.A.S. 3, Lenoir 1987; Legros 1991).

\section{Cleavage-fold relationship}

As previously mentioned by Legros (1991), a gradual change in cleavage dip occurs across the area (Fig. 2). From south to north, cleavage dip changes from $c$. $50^{\circ} \mathrm{NE}$ in outcrop N.A.S. 1 and the southern parts of outcrops N.A.S. 2 and 3, towards $c .80^{\circ} \mathrm{NE}$ in outcrop N.A.S. 4 and the northern parts of outcrop N.A.S. 2. Further north, cleavage remains steeply NE-dipping. This gradual change does not show any relationship with the limit between the Asquempont Member and the Ripain Member, nor with the trace of the Asquempont fault (Fig. 2).

Bedding is observed only in outcrops Ittre 3, N.A.S. 2 and 3, and locally in outcrop Oisquercq 1 (Fig. 2). Particularly in outcrop N.A.S. 2, bedding is commonly visible in outcrop (e.g. sedimentary ripples and thin volcanic intercalation) and in cases where bedding could not be observed, cut oriented hand specimens were used to determine bedding.

Outcrop N.A.S. 2 essentially consists of a steeply SW-dipping monocline containing metre- to decametre-scale folds. As 


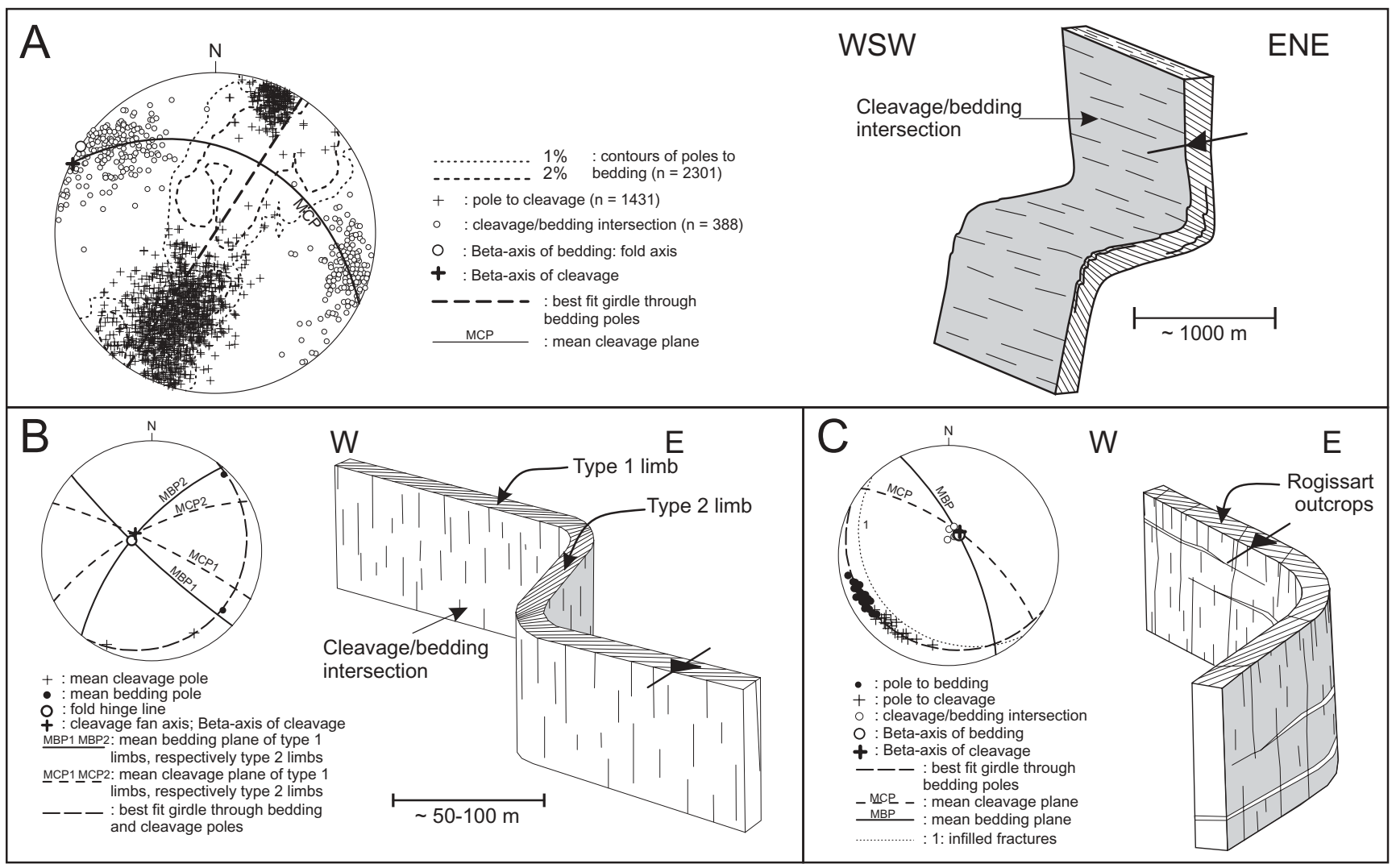

Fig. 3. Lower-hemisphere equal-area stereographic projections of (a) the subhorizontal to gently plunging folds in the Ordovician and Silurian sequence in the southern part of the Sennette valley (data from Debacker (2001), partly already incorporated in studies by Debacker et al. (1999, 2001, 2003)), (b) the steeply plunging folds at Lembeek (outcrops Lembeek 1-7; data from Sintubin et al. 1998), and (c) the steep, uniformly dipping beds at Rogissart (outcrops Rogissart 1 and 2), with the probable structural significance, taking into account the observations at Lembeek. Sketches of fold geometries are added for clarity. The younging direction is marked by arrows.

appears from bedding measurements and the orientation of the cleavage-bedding intersection, subhorizontal to gently plunging fold hinge-lines and associated intersection lineation take up a large part of the section and dominate the southern part of the outcrop (Fig. 4). These folds, labelled type A folds, strongly resemble the folds in the Ordovician-Silurian outcrop areas. The folds face upwards to the SW, have gentle to open interlimb angles and are asymmetric, with a SW-verging asymmetry and a stepfold-like geometry. Cleavage transection is common, predominantly anticlockwise (Fig. 5).

Between these zones of type A folds, zones with a moderately to steeply plunging cleavage-bedding intersection occur (Figs 4 and 5). Especially in the northern part of the outcrop the intersection lineation is steeply plunging and clearly differs from the cleavage-bedding intersection associated with the type A folds. Also, the bedding measurements suggest moderately to steeply plunging folds. These folds are termed type B folds.

On the basis of the orientation of bedding and the plunge of the cleavage-bedding intersection and fold hinge-lines, outcrop N.A.S. 2 can be subdivided into four large zones ( $>50 \mathrm{~m}$ wide), two containing type A folds (plunge $<35^{\circ}$ ), and two of which the data suggest are type B folds (plunge $>35^{\circ}$; Fig. 4). Between them, smaller zones may be distinguished (e.g. between $40825 \mathrm{~m}$ and $40850 \mathrm{~m}$ ). The two large zones with type B folds have slightly higher cleavage strike values than the two large zones with type A folds. This change in cleavage trend does not reflect the smaller zones.

Although the orientations of the type A folds and type B folds markedly differ, the evolution of the pitch of the cleavagebedding intersection and the fold hinge-line in the cleavage plane along outcrop N.A.S. 2 suggests that the transitions between the two fold types occur rather gradually (Figs 4 and 5). In addition, the changes in pitch indicate that the cleavage-bedding intersection, and therefore also the fold hinge-lines, passes not only through the horizontal but also through the vertical, locally resulting in downward facing folds (e.g. around 40800 m, Fig. 4). Along outcrop N.A.S. 2, the amount of axial cleavage transection, predominantly anticlockwise, seemingly decreases towards the north.

Outcrop N.A.S. 3 (Fig. 2) shows a similar cleavage-bedding relationship to outcrop N.A.S. 2. In outcrop Oisquercq 1 (Fig. 2) the few bedding and cleavage-bedding intersection measurements suggest the presence of gently NW-plunging, open to closed type A folds, with a slight SW-verging asymmetry and a small clockwise cleavage transection.

\section{Faults and slip planes}

Outcrop N.A.S. 2 contains a few fracture zones, post-dating cleavage development. Their outcrop trace usually suggests a steep NW- to NNW-trending orientation. Several of these zones, commonly containing fine crush breccias, occur around the transition between the different fold types (e.g. around $40830 \mathrm{~m}$ and between 40860 and $40870 \mathrm{~m}$ ).

Throughout outcrop N.A.S. 2 many surfaces contain lineations resembling poorly developed striations. Often, however, these 


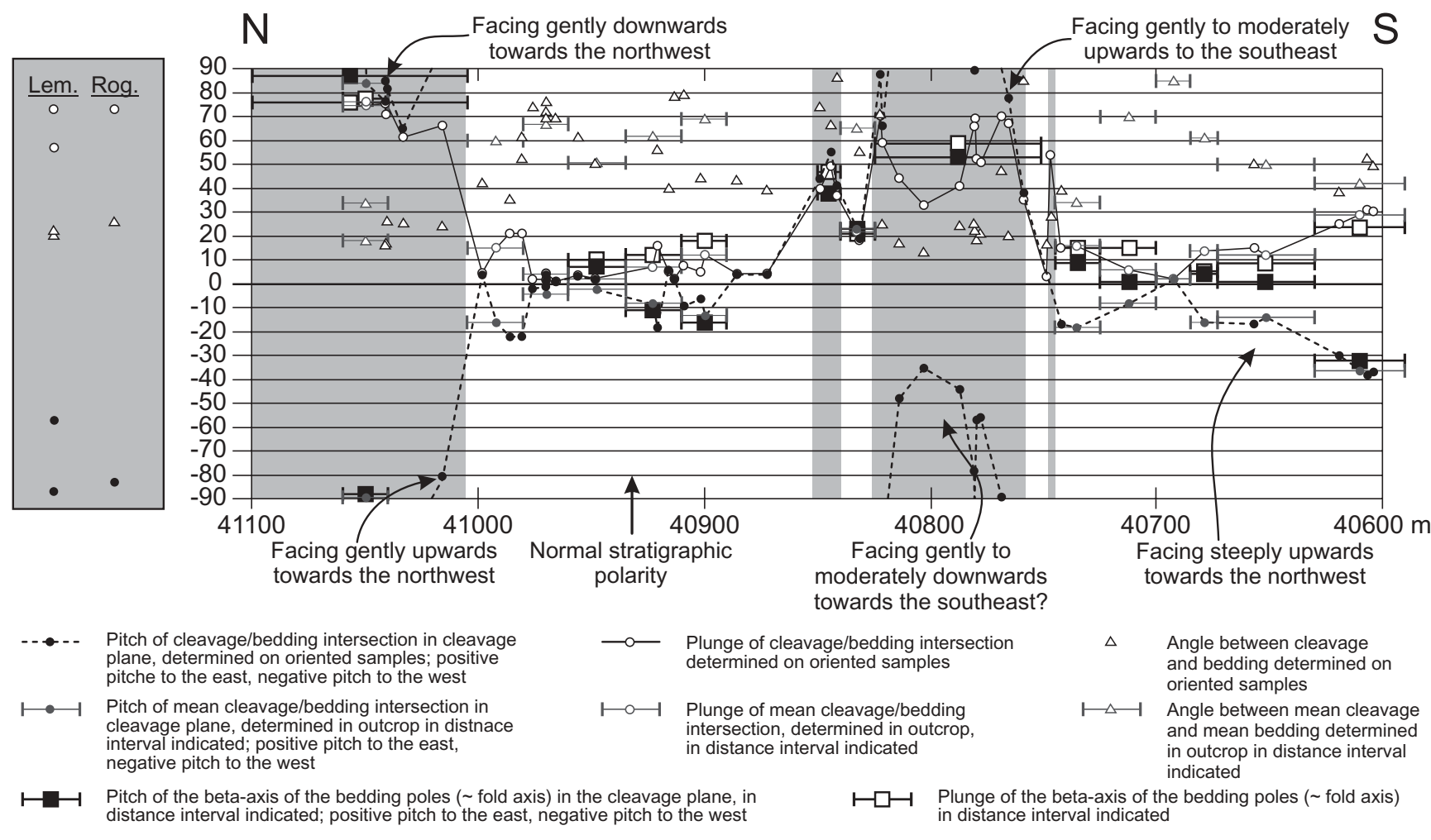

Fig. 4. Graph showing the changes in cleavage-bedding angle and the changes in plunge and pitch of the cleavage-bedding intersection and the beta-axis of bedding (c. fold axis) along outcrop N.A.S. 2. Distances are expressed in metres along east side of the canal. Using a plunge of $35^{\circ}$ as a limit, the section is divided into zones of type A folds (white) and zones of type B folds (grey). Two datasets were used to obtain the curves of the cleavagebedding intersection: individual measurements on oriented samples and mean values of orientation measurements performed on outcrop, averaged over a certain distance. For comparative purposes, the mean cleavage-bedding angle and the pitch and the plunge of the cleavage-bedding intersection are also shown in the limbs of the steeply plunging folds at Lembeek (Lem.) and Rogissart (Rog.). It should be noted that, although showing a rather gradual change across the outcrop, the evolution of the pitch of the cleavage-bedding intersection locally reflects downward facing folds (see Fig. 5).

can be shown to represent an intersection lineation (e.g. intersection with cleavage). Only those lineations of which the orientation deviates from an intersection lineation are considered. Three clusters are distinguished (Fig. 5). (1) In several places, a steeply to moderately NW-plunging striation occurs on subvertical to moderately dipping, NW-SE-trending bedding and cleavage planes. Similar features have been observed in other localities in the Sennette valley, and have been attributed to post-cleavage normal faulting (see Debacker 2001; Van Grootel et al. 2002; Debacker et al. 2003). (2) Within the zones of type A folds, locally a subhorizontal striation occurs on moderately southdipping bedding planes (e.g. at $40835 \mathrm{~m}$ ). The sense of movement and the tectonic significance of these slip planes are unknown. (3) In the large zone of type B folds in the northern part of the outcrop, locally a gently SE-plunging striation occurs, with a dextral sense of movement, on subvertical, beddingparallel surfaces (Fig. 5). Unless it reflects a more regional, bedding-parallel dextral shear, it may be possible that this striation, oriented at high angles to the local cleavage-bedding intersection (66/006-75/063), results from flexural slip during development of the type B folds.

\section{Fabric analysis}

Microscopic observations. In both members a large amount of white mica is present, oriented parallel to the rather poorly developed cleavage. Well-developed cleavage domains appear to be absent and white mica occurs throughout the rock mass. Only occasionally (often around chlorite-mica stacks) do cleavageparallel anastomosing alignments of darker material, resembling poorly developed cleavage domains, become apparent. In general, the cleavage domains are better developed in the Ripain Member than in the Asquempont Member. Also, the alignment of white mica is more pronounced in the Ripain Member. This is compatible with the macroscopic cleavage, which has a better developed, slaty appearance in the Ripain Member. Chloritemica stacks oriented parallel to cleavage as well as stacks oriented parallel to bedding occur, the latter having lower aspect ratios than the former. The relative orientation of the chloritemica stacks with respect to cleavage suggests a disjunctive cleavage.

Phyllosilicate preferred orientation. Phyllosilicate X-ray pole figure goniometry was applied on 11 samples from outcrop N.A.S. 2 (Debacker et al. 2004; for methods see Sintubin 1994). The pole figures can be found in Supplementary Publication No. SUP18199 (see p. 000).

Two types of pole figure patterns are distinguished. The first type, obtained from samples of the Asquempont Member, shows a girdle pole figure pattern, which is generally more pronounced for white mica than for chlorite, and a relatively weak degree of preferred orientation, which is higher for chlorite than for white 


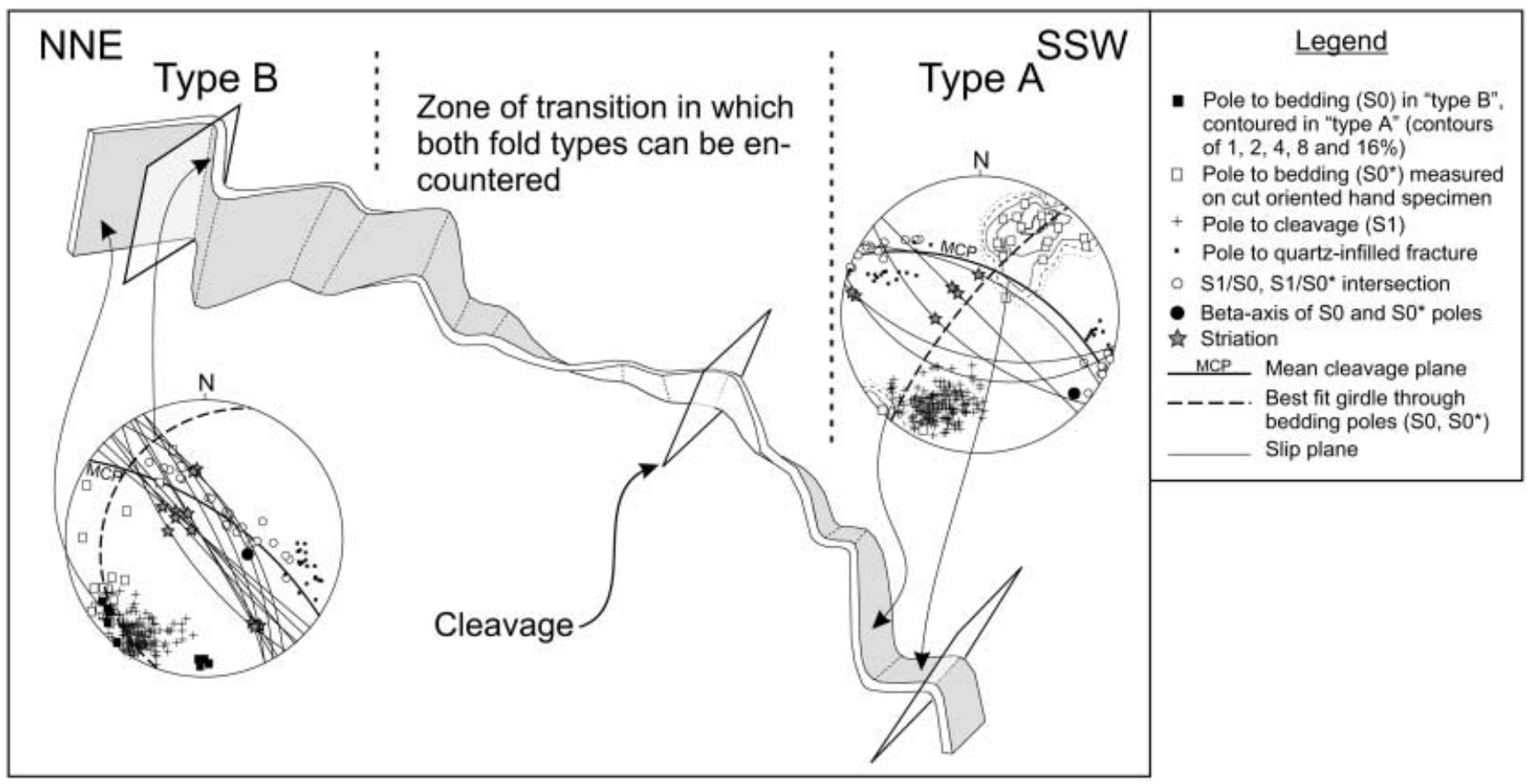

Fig. 5. Schematic representation of bedding geometry within the transition zone between type A folds to the south and type B folds to the north, based on the observations along outcrop N.A.S. 2 (see Fig. 4), with two lower-hemisphere equal-area stereographic projections with the structural data related to the type A and type B folds in outcrop N.A.S. 2.

mica, and different pole figure maxima for chlorite and for mica. These characteristics are typical for an intersection fabric (see Sintubin 1994). The mica pole figure maxima coincide with the cleavage pole, whereas the chlorite pole figure maxima approximate the bedding poles. This difference in pole figure maxima is compatible with the angle between bedding and cleavage: large (small) differences between chlorite and mica pole figure maxima occur for samples with a large (small) angle between bedding and cleavage. Dealing with intersection pole figure patterns, the short axis of the girdle should correspond to the cleavage-bedding intersection. Indeed, pole figure patterns from zones with type A folds have subhorizontal to gently plunging orientation distribution short axes, whereas those from zones with type $\mathrm{B}$ folds have plunging orientation distribution short axes.

The second type, from samples of the Asquempont Member and the Ripain Member, is characterized by a moderate, occasionally weak preferred orientation. The maxima of both white mica and chlorite coincide with the cleavage pole. The pole figure patterns have an axial symmetrical to slightly orthorhombic shape and suggest predominantly flattening fabrics (see Sintubin 1994). Orthorhombic pole figure patterns can be interpreted as reflecting an intersection fabric if the orientation distribution short axis coincides with the cleavage-bedding intersection (see the description of the first type). If, however, the short axis markedly differs from the cleavage-bedding intersection, the pole figure patterns may reflect a small cleavage-parallel stretch at high angles to the cleavage-bedding intersection. The shape and the higher amount of preferred orientation of the second type of pole figure patterns as compared with the first type possibly results from the rather small angle between bedding and cleavage (Debacker et al. 2004). The phyllosilicate preferred orientation data thus reflect the presence of zones with a moderately to steeply plunging intersection lineation between zones with a subhorizontal to gently plunging intersection lineation. The degree of alignment is compatible with a poorly to moderately developed cleavage, governed by white mica, acting on a bedding-parallel fabric reflected by chlorite.

\section{Discussion}

\section{Cleavage-fold relationship and related features}

The type A folds have the same geometric characteristics as the subhorizontal to gently plunging folds in the Ordovician and Silurian outcrop areas and therefore are also considered as type A folds. Also, the type B folds show many similarities to the steeply plunging folds in the Lembeek-Rogissart area. The steep plunge of the cleavage-bedding intersection, the orientation of bedding and the $c .020^{\circ}$ anticlockwise angle between bedding and cleavage are almost identical to what is observed in the type 1 limbs (Figs 3 and 4). Because of these similarities, the folds in the Lembeek-Rogissart area are also considered as type B folds.

As indicated by the cleavage-bedding relationships and the intersection pole figure patterns, outcrop N.A.S. 2 forms a transition zone between the two fold types, characterized by the alternating presence of type A and type B folds. To a certain extent, the orientation of the cleavage reflects this zonation. The slightly higher cleavage strike values in the two large zones of type B folds as compared with the two large zones of type A folds may be related to the difference in overall bedding attitude: predominantly subvertical to steeply ENE-dipping, NNW-SSEtrending limbs in the type B fold zones, and predominantly moderately to steeply SW-dipping bedding with a NW-SE trend in the type A fold zones.

The observations in outcrop N.A.S. 2 indicate that the transition between the two fold types occurs repeatedly and gradually (Figs 4 and 5). Also, the gradual stratigraphic transition between 
the two members of the Oisquercq Formation and the cartographic distribution of the stratigraphy in the AsquempontIttre-Oisquercq area suggest a gradual transition in the absence of important structural discontinuities. However, although of a gradual nature, the transition between type A folds and type B folds is expected to cause geometric difficulties (Fig. 5). Possibly the fracture zones along the transitions between the type A folds and type B folds formed to accommodate this.

\section{Transition geometry based on the cleavage-fold relationship}

As suggested by the cleavage-fold relationship and the stratigraphic polarity, it is the steep limbs of the type A folds that transform into the type 1 limbs of the type B folds. The data for the study area illustrate the way in which this transition occurs. This is represented by means of two synthetic stereographic projections in Figure 6. Starting from a steep limb of a type A fold (numbers 1, 2 and stages A, B in Fig. 6), a transition to a type 1 limb of a type B fold (numbers $3,4,5$ and stages D, E in Fig. 6) necessitates three conditions to be fulfilled. First, bedding trend has to rotate slightly in a clockwise fashion, whereas its dip has to become steep to subvertical. Second, cleavage dip has to increase. Depending on bedding orientation, simultaneously a slight clockwise rotation of cleavage trend may occur. Third, these changes have to result in a $c .020^{\circ}$ anticlockwise angle between bedding and cleavage in the type 1 limbs, the angle being a function of lithology, relative amount of bedding compaction and folding mechanism (see Ramsay \& Huber 1983; Sintubin et al. 1998).

All three conditions seem fulfilled in the Asquempont-IttreOisquercq area, in particular along outcrop N.A.S. 2. A regional clockwise change in bedding trend occurs (see Debacker et al. 2001), leading to subvertical to slightly overturned NNW-SSEtrending bedding in the northern part of outcrop N.A.S. 2. The second condition suggests that the observed large-scale change in cleavage dip (Figs 2 and 5) is likely to be related to the transition between the two fold styles. The third condition is essentially a result of the first two conditions and may offer an explanation for the locally high degree of cleavage transection. As the fold style transition occurs repeatedly, leading to type B folds between type A folds and vice versa (Figs 4 and 5), whereas the northward increase in cleavage dip occurs progressively (Figs 2 and 5), a locally pronounced cleavage transection
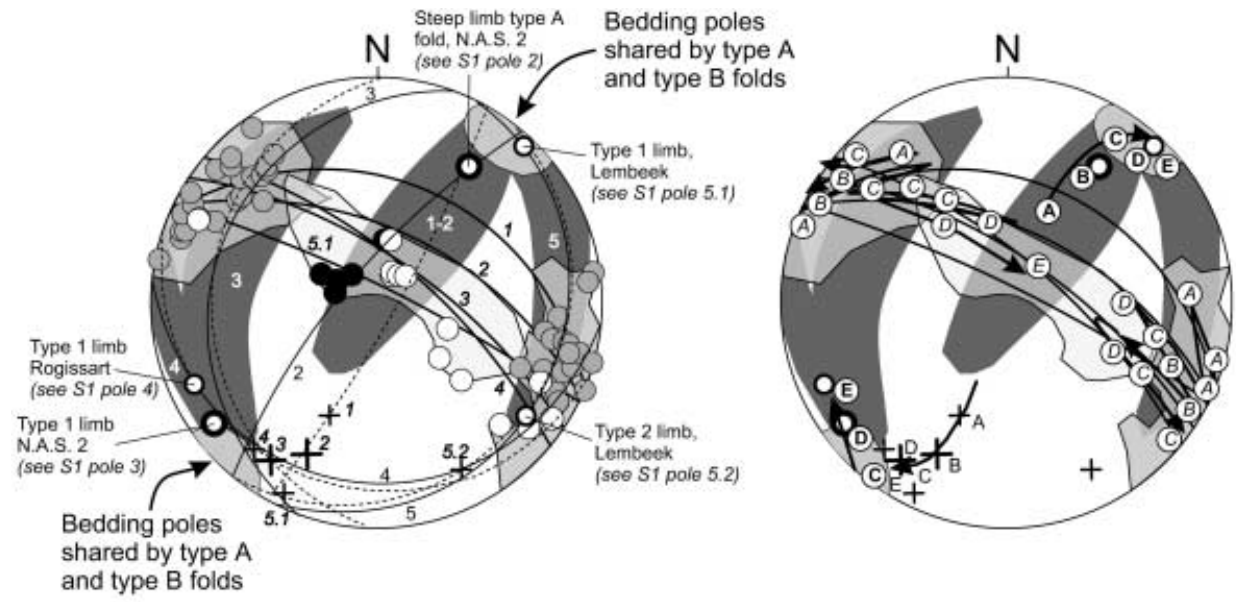

Progressive increase in cleavage dip and bedding trend (clockwise rotation)

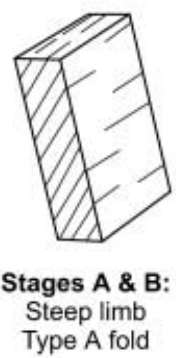

$\mathrm{N}$

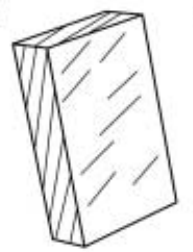

Stage C: transition zone: depending on relative orientation of bedding and cleavage, a variety in cleavage/fold relationships is expected

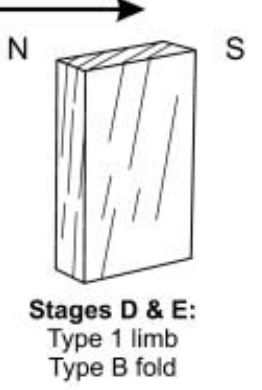

- Mean bedding pole of steep fold limbs in outcrop N.A.S. 2

- Mean bedding pole of type $1 /$ type2 limt of type B folds at Lembeelv/Rogissart

+ Mean cleavago (S1) pole of type A/type B fold in outcrop N.A.S.

+ Mean cleavage (S1) pole of type 1/type2 limb of type B folds at Lembeek'Rogissart Fold hinge line of type A fokd in SilurianOrdovician part of Sennette valley

- Fold hinge line of type B fold at Lembeek Rogissart

Fold A fosds) in cutcrop NA.S. 2

Range of bec Range of bedding poles in type $A$ and type B folds; 1: type A folds SilurianOrdovician; 2 type A folds N.A.S. 2; Rogert; 5 : Nype B folds Leme Rogssant 5 Hype B blas Lembeek Range of cleavage/bedding intersections and fold hinge lines associated with type A folds (Ordovician-Silurian and N.A.S. 2)

Range of cleavage/bedding intersec tions and fold hinge lines associated with type B folds (N.A.S. 2, Rogissart. Lembeek)

Mean cleavage (S1) plane in type A and type B folds; 1: type A tolds Silunian-Ordovician; 2: type A folds N.A.S, 2; 3: type B folds N.A.S. 2; 4 ; type B fold Rogissart, 5: type B folds Lemben Best fit gircle through bedding poles (numbers 2 to 5: see above) Best fit gircle through bedding and cleavage poles (numbers 2 to 5 : cleavage prove)

(A) Passible fold hinge line orientations assofrom type A folds (etages A. B) to type B folds (stages D, E)

(A) Bedding orientations associated with various stages in the transition from the steep limb of 1 limb of type $B$ folds (atages D, E)

Fig. 6. Evaluation of the transition from a type A fold to a type B fold. The transition occurs via the steep limb of a type A fold towards the type 1 limb of a type B fold, as shown schematically in the lower part of the figure, and represented by means of two synthetic lower-hemisphere equal-area stereographic projections in the upper part of the figure. The left projection shows structural data from five localities in the Sennette valley: 1, type A folds in the Ordovician-Silurian southern part; 2, type A folds in outcrop N.A.S. 2; 3, type B folds in outcrop N.A.S. 2 ; 4, type 1 limbs at Rogissart; 5 , the limbs of the type B folds at Lembeek (5.1, the type 1 limbs; 5.2, the type 2 limbs). The structural data include the mean cleavage orientation and the range of bedding poles associated with each locality, the orientation distribution of the cleavage-bedding intersection and fold hinge-lines of type A folds and type B folds, and the mean orientation of the steep limbs of the type A folds in outcrop N.A.S. 2 and of the limbs of the type B folds at Rogissart and Lembeek. The right projection shows the same datasets, but labelled in terms of the five stages schematically represented in the lower part of the figure. According to the data, the presence of a subvertical limb and a steep cleavage are a necessity for the fold transition. 
is likely. The apparent northward decrease in cleavage transection angle along outcrop N.A.S. 2 seems compatible with this reasoning.

Although all three conditions are met in outcrop N.A.S. 2, the apparent distribution of type A and type $\mathrm{B}$ folds in the Asquempont-Ittre-Oisquercq area suggests that, instead of containing the transition zone, this outcrop forms only part of a large-scale transition zone that extends further to the north. This is compatible with observations by Vander Auwera (1983) of both steeply plunging and gently plunging folds in the Lower Cambrian Tubize Formation at 'Forges de Clabecq' (F.d.C. in Fig. 2).

Both the type 1 limbs of the steeply plunging folds of the Lembeek-Rogissart area (Vander Auwera 1983; Sintubin et al. 1998) and the regional stratigraphy indicate a SW younging of the deposits. Taking into account the predominantly gently NWplunging folds in the Ordovician and the southern part of the Oisquercq Formation in the Asquempont area (Debacker 2001; Debacker et al. 2001, 2003), a progressive northward steepening of the plunge of the fold hinge-lines would be expected across the transition zone, from gently NW-plunging, upward facing in the south, to steeply north-plunging, westward facing in the north. This progression would necessitate a change in fold plunge-pitch of only $<90^{\circ}$ (from $0^{\circ}$ to $c .70^{\circ} \mathrm{N}$ ). However, many folds along outcrop N.A.S. 2 reflect a SE-directed upward facing arrangement (Figs 4 and 5). In addition, as suggested by the changes in pitch of the cleavage-bedding intersection (Fig. 4), fold hinge-lines pass through the vertical as well as through the horizontal and locally downward facing folds can be inferred. As such, the transition between type A and type B folds does not simply consist of a progressive increase in NW-directed plunge. Instead, along outcrop N.A.S. 2, the plunge direction and the facing direction also are highly variable. This implies a change in plunge or pitch exceeding $90^{\circ}$. As such, in the transition zone, fold hinge-line orientation is more variable (change in plunge or pitch $>90^{\circ}$ ) than suggested by the repetitive occurrence of type $\mathrm{A}$ and type $\mathrm{B}$ folds (expected change in plunge or pitch $<90^{\circ}$ ), leading to adjacent zones in which fold hinge-lines have completely different plunges and plunge directions, resulting in folds with different facing directions (Figs 4 and 5). This implies curvilinear fold hinge-lines.

\section{Strain partitioning}

The change in fold orientation in the southern part of the Brabant Massif, from type A folds in the south to type B folds in the north, reflects large-scale strain partitioning. Within the transition zone between the type A and type B folds it appears as if the fold hinge-lines, although attempting to remain in the cleavage plane, continuously change in orientation to find the most suitable orientation for the strain regime (Fig. 6). This variation in fold hinge-line orientation may reflect a strong variation in the orientation of the $x$ - and $y$-axes of the finite strain ellipsoid, and, on the assumption of a uniform compaction, a strong variation in the $x$ - and $y$-axes of the tectonic strain. Following this hypothesis, either both tectonic axes were well defined (i.e. having a large difference, e.g. plane strain and prolate strain) and strongly changed in orientation across the transition zone or, alternatively, both axes were poorly defined (i.e. practically equal: oblate strain). Considering the very homogeneous lithology, the planar nature of the cleavage and the rather irregular nature of the changes in fold hinge-line orientation, the second possibility seems more likely. Hence, we tentatively suggest that the strong variation in fold hinge-line orientation may be a result of a bulk oblate tectonic strain within the transition zone.

Similar zones containing asymmetric, steeply plunging folds adjacent to gently plunging folds with strong variations in facing directions and curvilinear fold hinge-lines have been attributed to strain partitioning in transpression zones (Holdsworth et al. $2002 b$ ). On the basis of cleavage-fold relationships, Holdsworth et al. (2002b) distinguished four domains in a $500 \mathrm{~m}$ wide sinistral transpression zone in the Southern Uplands Terrane: domain 1, with steeply SW-plunging folds with an S-fold geometry; domain 2, with subhorizontal, NE-SW-trending, upward facing folds; domain 3, with moderately to steeply plunging, strongly curvilinear folds with a sinistral vergence within a NE-SW-striking, subvertical homocline; domain 4, with subhorizontal to moderately plunging folds, locally strongly curvilinear, affected by sinistral detachments (Holdsworth et al. 2002b). The type B folds of the Brabant Massif resemble the folds of domain 1, the type A folds closely correspond to the folds of domain 2, and the fold transition zone shows similarities to both domains 3 and 4 . Furthermore, the relative position of the fold transition zone is comparable with that of domains 3 and 4, situated between domains 1 and 2 and between two domains 2, respectively. However, whereas Holdsworth et al. (2002b) depicted the various domains with abrupt boundaries, and suggested that the deformation in domain 1 is partitioned into domains 2 and 3, in the Brabant Massif gradual transitions are observed and the zone resembling domains 3 and 4 is considered as a transition zone between the type A and type B folds.

The domains in the Southern Uplands form part of a transpression zone related to the oblique closure of the Iapetus Ocean (Soper \& Hutton 1984; Soper et al. 1992). In contrast, although oblate strains, as inferred in the transition zone, are considered a common feature in transpression zones (Sanderson \& Marchini 1984; Fossen \& Tikoff 1993; Dewey et al. 1998) and the Zshaped geometry of the type B folds may be compatible with a dextral shear during contraction, we do not have field evidence for an overall transpressive deformation. However, interpretations of geophysical data suggest that transpressive movements are likely to have occurred in this part of the Brabant Massif.

\section{Geophysical data and comparison with outcrop data}

In the SW part of the Brabant Massif a large, NW-SE-trending negative Bouguer anomaly occurs (Jones 1948; De Meyer 1983; Chacksfield et al. 1993; De Vos et al. 1993a; Lee et al. 1993), modelled as a steep-sided low-density body with a roof at between 1 and $2 \mathrm{~km}$ depth in the shallowest parts (Fig. 7; Everaerts et al. 1996; De Vos 1997). Considering the overall NNE-SSW-directed shortening direction, deduced from outcrop observations (Sintubin 1999; Debacker 2001), the obliquity between the shortening vector and the pole to the steep NE margin of this low-density body is expected to give rise to a dextral transpression (Fig. 7; see Sintubin, 1999).

The NE margin of the low-density body coincides with an important NW-SE-trending aeromagnetic lineament, the Asquempont lineament (Fig. 7; Sintubin \& Everaerts 2002). To the $\mathrm{SE}$, this lineament extends in the Asquempont-Ittre-Oisquercq area, where it underlies the fold transition zone (Fig. 8; compare Fig. 7). It also forms the southwestern limit of the aeromagnetic high of the Brabant Massif, attributed to the magnetite-bearing Lower Cambrian Tubize Formation and possibly older deposits (De Vos et al. 1992; Chacksfield et al. 1993; Lee et al. 1993; Everaerts et al. 1996). Within the aeromagnetic high, several more aeromagnetic lineaments are present, oriented subparallel 


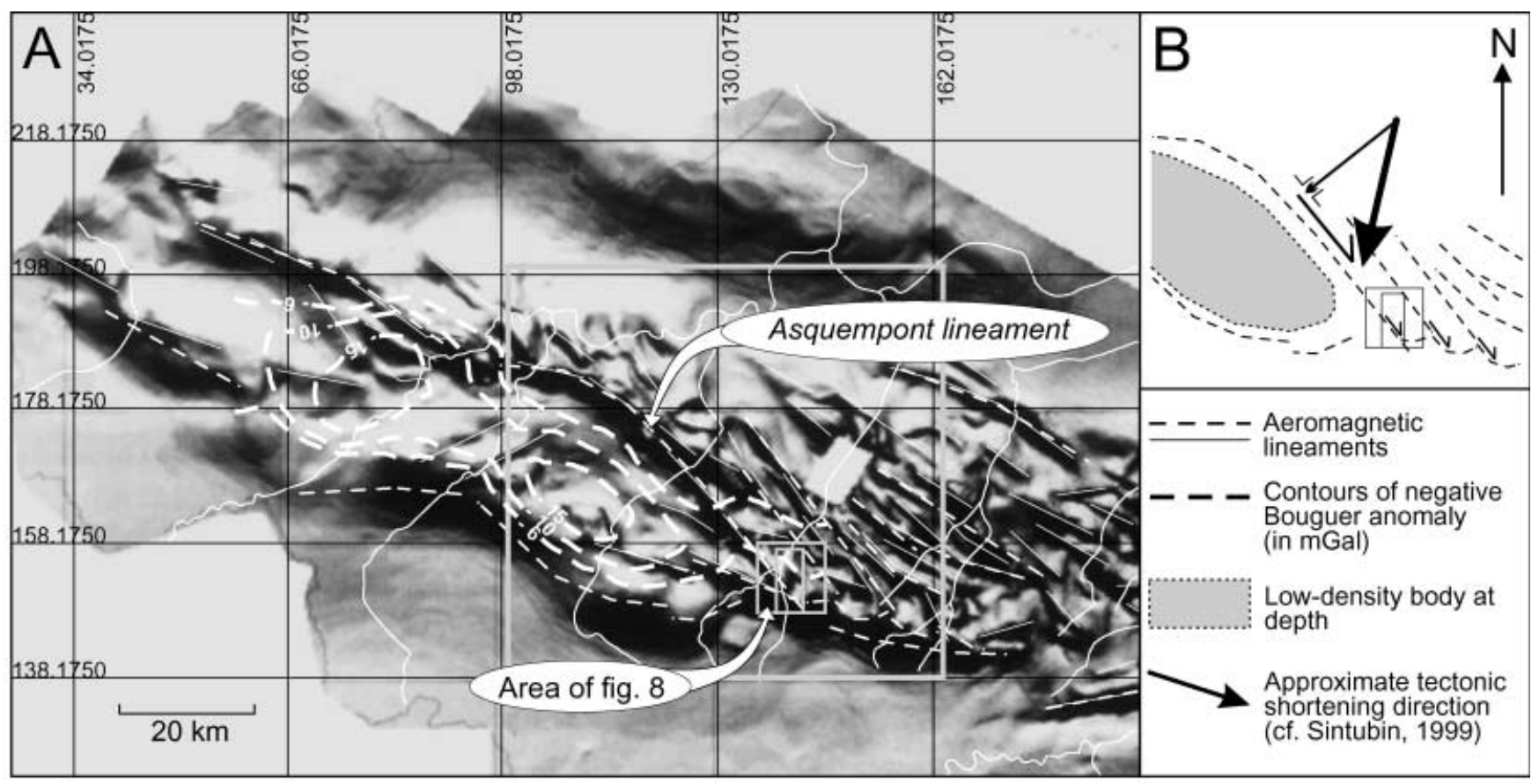

Fig. 7. (a) Aeromagnetic map of the Brabant Massif, reduced to the pole with a pseudo-illumination from the NE (De Vos et al. 1993a), on which the most apparent aeromagnetic lineaments are traced. Also shown are the gravimetric contours (in mGal) of the negative Bouguer anomaly in the southwestern part of the Brabant Massif (taken from De Vos 1997). To aid orientation, Belgian Lambert coordinates (in km) are shown and the areas of (b) and Figure 8 are outlined. (b) Schematic representation of the central part of (a), demonstrating the obliqueness between the approximate tectonic shortening direction (Sintubin 1999; Debacker 2001) and the normal to the steep NE margin of the low-density body, probably resulting in a dextral transpression.

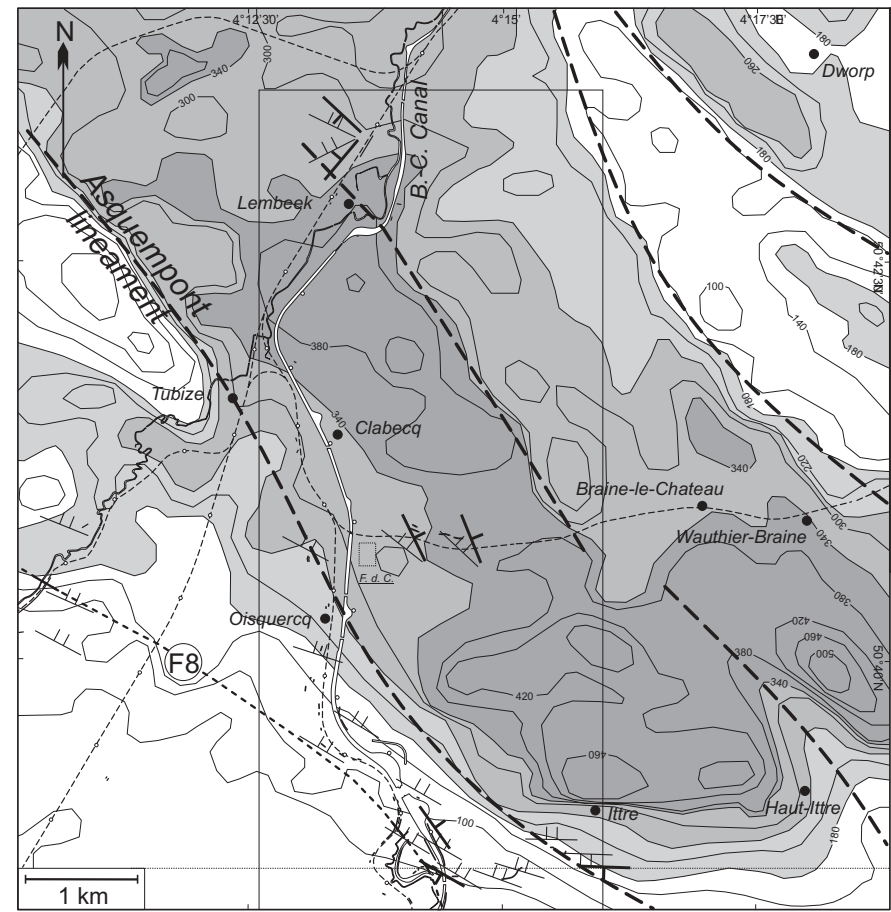

to the Asquempont lineament (De Vos et al. 1993a; Belgian Geological Survey 1994). Like the latter, these have been interpreted as steep faults or shear zones (Chacksfield et al. 1993), with a dextral to reverse displacement (Everaerts et al. 1996; Sintubin 1997b, 1999; Van Grootel et al. 1997; Sintubin et

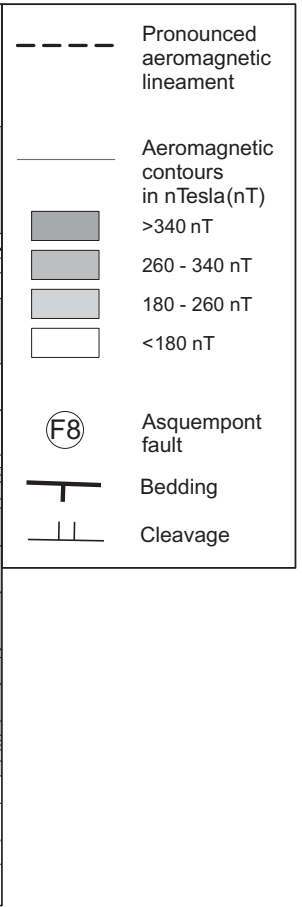

Fig. 8. Simplified map of the study area, showing the aeromagnetic contours (in $\mathrm{nT}$; Belgian Geological Survey 1994), the trace of the Asquempont fault (Debacker et al. 2003), the mean cleavage and bedding orientations, and the traces of the most pronounced aeromagnetic lineaments. The rectangular frame marks the area of Figure 2.

al. 1998; Mansy et al. 1999). Whereas the reverse movement is mainly based on the erroneous equation of the Asquempont lineament with the Asquempont fault as described by Legrand (1967), the dextral sense of movement is based on the step-like, lobe-shaped morphology of the southern margin of the aeromag- 
netic high (Fig. 7; Sintubin 1997b, 1999; Sintubin et al. 1998; Mansy et al. 1999). Hence, there are some indications for dextral transpression along the NE margin of the low-density body, in particular along the Asquempont lineament (see Sintubin et al. 1998; Sintubin 1999). However, seemingly in contrast to what would appear from the geophysical data, there are no indications of an important structural break at the present-day outcrop level.

Unlike the pronounced NW-SE-trending aeromagnetic lineaments, the geological significance of the less pronounced, shorter features within and along the southern rim of the aeromagnetic high remains debated. Many claim these reflect folds (Chacksfield et al. 1993; Mansy et al. 1999); others see them as parallel to the cleavage trajectories (Sintubin 1999), or as reflecting faults or shear zones (Sintubin 1997b; Debacker 1999). Because aeromagnetic anomaly highs (lows) are caused by the presence of rocks with a high (low) magnetic susceptibility, and magnetite in the Lower Cambrian Tubize Formation occurs in bedding-parallel zones (de Magnée \& Raynaud 1944; Vander Auwera \& André 1985; De Vos et al. 1992; Everaerts et al. 1996), the aeromagnetic maps should essentially reflect bedding and possible faults or shear zones bringing into contact rocks with different magnetic susceptibilities (see de Magnée \& Raynaud 1944). Hence, the aeromagnetic contours should follow the trend of the fold hinge-lines and the cogenetic cleavage in areas with type A folds, but are expected to be oblique to the cleavage within areas of type B folds. An example of the latter case is the Lembeek-Rogissart area (Fig. 8), where the aeromagnetic contours are oblique to the cleavage, and subparallel to the trend of the type 1 limbs. The Ittre area may serve as an example of the former case. Although several workers (Sintubin 1997b, 1999; Mansy et al. 1999) considered the lobes along the south side of the aeromagnetic high as north-dipping thrusts, the close relationship between the aeromagnetic contours and the outcrop data from the Ittre area (type A cleavage-bedding relationship; Fig. 8) leads us to suggest that the lobes may simply reflect the steep stratigraphic contact between the magnetitebearing Tubize Formation at depth and the overlying nonmagnetic Oisquercq Formation, probably being affected by dextral shear along the Asquempont lineament (see Sintubin et al., 1998).

\section{Model for the southern part of the Brabant Massif}

Figure 9 shows a conceptual model of the southern part of the Brabant Massif, in which both the field observations and the aeromagnetic data are incorporated, keeping in mind a gradual transition between type A folds and type B folds at the presentday outcrop level.

Following the ideas of Sintubin $(1997 b, 1999)$ and others (e.g. Sintubin et al. 1998; Mansy et al. 1999), the Asquempont lineament is interpreted as a deep-seated basement structure that acted as a dextral transpressive shear zone during shortening. Similarly, the pronounced NW-SE-trending aeromagnetic lineaments within the aeromagnetic high of the massif are interpreted as dextral shear zones, formed as a result of dextral transpression. This dextral transpression is considered a local phenomen-

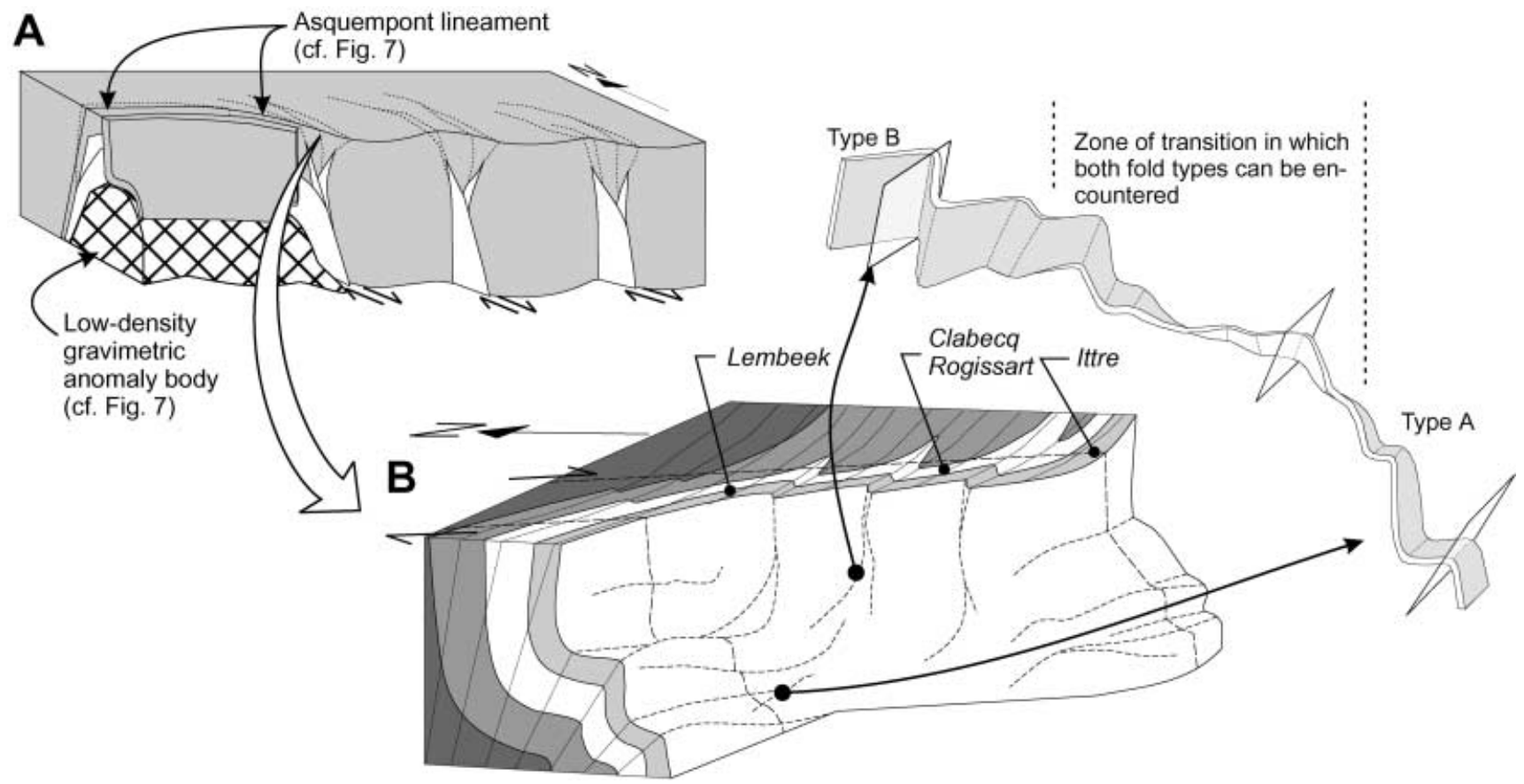

Fig. 9. Conceptual model of the fold transition zone, based on outcrop observations and geophysical data. (a) The southern margin of the Lower Cambrian core viewed from the SW. The core was compressed against the low-density gravimetric anomaly body, thus experiencing a steepening and giving rise to a steep belt (Sintubin 1999). Parts of the core were thrust over the roof of this low-density body (Debacker 1999) and a large part of the steep core experienced a dextral transpressive movement along the NE side of this body, with the development of dextral shear zones, visible as pronounced aeromagnetic lineaments (see Sintubin et al. 1998; Sintubin 1999; Verniers et al. 2002). At depth, the Asquempont lineament partly coincides with the NE margin of the low-density body. At more shallow levels the dextral movement was accommodated in a more gradual fashion, by means of Zshaped type B folds, showing a gradual transition towards the type A folds. (b) Detailed view of the fold transition zone in the Ittre-AsquempontLembeek area, with the approximate positions of the outcrop areas and the fold train depicted in Figure 5. It should be noted that, for convenience, all outcrop areas are placed along the Asquempont lineament, whereas in reality Lembeek appears to be situated along another lineament (see Fig. 8). 
on, resulting entirely from the obliquity between the normal to the steep NE margin of the low-density body at depth and the NNE-SSW-directed shortening (see Sintubin 1997b, 1999; Sintubin et al. 1998; Mansy et al. 1999). Both the type B folds and the transition between the type B and type A folds are attributed to these transpressive movements.

The aeromagnetic data suggest that the Asquempont lineament corresponds to a tectonic break, which is not evidenced at the present-day outcrop level. Also, the low strains indicated by the relatively low degree of phyllosilicate preferred orientation within the fold transition zone seem difficult to reconcile with the high strains expected in a shear zone. However, as the transpression essentially results from the presence of the low-density body at depth, the dextral shear zone originated at depth and its influence is likely to decrease upwards. Probably, the dextral displacement at depth is accommodated in a more gradual fashion at the present-day outcrop level by means of the type B folds and the fold transition zone. This is compatible with observations by Holdsworth et al. (2002b) in the sinistral transpression zone in the Southern Uplands of steeply plunging S-shaped folds rooting downwards into sinistral strike-slip detachments.

\section{Conclusions}

A gradual transition exists between the subhorizontal type A folds and the steeply plunging type $\mathrm{B}$ folds in the Brabant Massif. The transition zone, a NW-SE-trending zone of 1$1.5 \mathrm{~km}$ width, is characterized by a strong variation in fold hinge-line orientation, with the occurrence of zones of type B folds between zones of type A folds and vice versa. The transition between the two fold types consists of the steep limbs of the type A folds transforming into the type 1 limbs of the type $B$ folds. This transformation mainly occurs by means of a largescale change in cleavage dip and a change in bedding strike, locally resulting in a marked cleavage transection. Within the transition zone, there is much more variation in fold hinge-line orientation than would be expected from a comparison of the type B and type A folds. This strong variation in fold hinge-line orientation, implying strongly curvilinear fold hinge-lines, is tentatively interpreted to result from oblate bulk tectonic strain.

The transition zone shows similarities with domains 3 and 4 of Holdsworth et al. (2002b) in the Southern Uplands. Based on the observations in the Brabant Massif, it might be suggested also that, in the Southern Uplands, domains 3 and 4 of Holdsworth et al. (2002b) represent a transition between zones of steeply plunging (type $\mathrm{B}$, domain 1) and gently plunging folds (type A, domain 2). However, within the Southern Uplands the domains seem to be separated by faults, whereas the study area appears to be characterized by a gradual fold transition, without evidence for important faults at the present-day outcrop level. Hence, within heterogeneous transpression zones, characterized by a partitioning into various deformation domains (Jones \& Tanner 1995), the domains are not necessarily always fault bounded.

The transition zone and the zone of type B folds appear to root down into a steep dextral shear zone, for which there is no direct evidence at the surface. This implies not only a lateral strain-deformation partitioning, resulting in zones of type B folds, zones of type A folds and transition zones, but also a vertical strain-deformation partitioning, with the zones of type $\mathrm{B}$ folds and the transition zones at the surface rooting downwards into steep dextral shear zones. This probably reflects a gradual transition from a predominantly heterogeneous transpression at depth to a less heterogeneous (more homogeneous) transpression at the present-day outcrop level (see Jones \& Tanner 1995).

We are grateful to R. E. Holdsworth, M. van Noorden and B. Vanhoecke for commenting on an earlier version of the manuscript, and very much appreciate the very constructive remarks of A. Maltman, R. Jones and W. De Vos, which led to significant shortening of the paper. This work mainly results from the $\mathrm{PhD}$ research of T.N.D. as a Research Assistant of the Fund for Scientific Research, Flanders (F.W.O.-Vlaanderen, Ghent University, 1997-2001). Currently, T.N.D. is a Postdoctoral Fellow of the F.W.O.-Vlaanderen. M.S. is a Research Associate of the Onderzoeksfonds K.U.Leuven. This work forms part of research project G.0094.01 of the F.W.O.-Vlaanderen.

\section{References}

Alsop, I. \& Holdsworth, R.E. 1993. The distribution, geometry and kinematic significance of Caledonian buckle folds in the western Moine Nappe, northwestern Scotland. Geological Magazine, 130, 353-362.

Alsop, I. \& Holdsworth, R.E. 1999. Vergence and facing patterns in large-scale sheath folds. Journal of Structural Geology, 21, 1335-1349.

Alsop, I. \& Holdsworth, R.E. 2002. The geometry and kinematics of flow perturbation folds. Tectonophysics, 350, 99-125.

Belgian Geological Survey 1994. Aeromagnetic map of the Brabant Massif: residual total field reduced to the pole. Scale 1/100000.

Belmans, M. 2000. Structurele geologie van het Siluur uit de Orneauvallei, Massief van Brabant. MS. thesis, Universiteit Gent.

Chacksfield, B., De Vos, W. \& D'hooge, L. ET AL. 1993. A new look at Belgian aeromagnetic and gravity data through image-based display and integrated modelling techniques. Geological Magazine, 130, 583-591.

Cobbold, P.R. \& Quinquis, H. 1980. Development of sheath folds in shear regimes. Journal of Structural Geology, 2, 119-126.

Coward, M.P. \& PotTs, G.J. 1983. Complex strain patterns developed at the frontal and lateral tips to shear zones and thrust zones. Journal of Structural Geology, 5, 383-399.

DeBACKER, T.N. 1999. Folds trending at various angles to the transport direction in the Marcq area, Brabant Massif, Belgium. Geologica Belgica, 2, 159-172.

DeBacker, T.N. 2001. Palaeozoic deformation of the Brabant Massif within eastern Avalonia: how, when and why? $\mathrm{PhD}$ thesis, Universiteit Gent.

Debacker, T.N. 2002. Cleavage/fold relationship in the Silurian of the MehaigneBurdinale area, southeastern Brabant Massif, Belgium. Geologica Belgica, 5, $3-15$.

Debacker, T.N., Sintubin, M. \& Verniers, J. 1999. Cleavage/fold relationships in the Silurian metapelites, southeastern Anglo-Brabant fold belt (Ronquières, Belgium). Geologie en Mijnbouw, 78, 47-56.

Debacker, T.N., Sintubin, M. \& Verniers, J. 2001. Large-scale slumping deduced from structural and sedimentary features in the Lower Palaeozoic Brabant Massif, Belgium. Journal of the Geological Society, London, 158, 341-352.

Debacker, T.N., Sintubin, M. \& Verniers, J. 2002. Timing and duration of the progressive deformation of the Brabant Massif, Belgium. Aardkundige Mededelingen, 12, 73-76.

Debacker, T.N., Herbosch, A., Verniers, J. \& Sintubin, M. 2003. Palaeozoic deformation history of the Asquempont-Virginal area (Brabant Massif, Belgium): large-scale slumping, low-angle extensional detachment development (the Asquempont Fault redefined) and normal faulting (the Nieuwpoort\&Asquempont fault zone). Memoirs of the Geological Survey of Belgium, 49, $1-30$.

Debacker, T.N., Robion, P. \& Sintubin, M. 2004. The complexity of the anisotropy of magnetic susceptibility (AMS) in low-grade, cleaved pelitic rocks: influence of cleavage/bedding angle and type and relative orientation of magnetic carriers. In: JaCKson, M., Luneburg, C., Aubourg, C. \& Martin-Hernandez, F. (eds) Title. Geological Society, London, Special Publications, $\mathbf{x x}, \mathrm{xx}-\mathrm{Xxx}$.

De Magnée, I. \& Raynaud, J. 1944. Etude magnétique de la tectonique du Cambrien du Brabant à l'est de Court-St-Etienne. Annales de la Société Géologique de Belgique, 67, 495-546.

De Meyer, F. 1983. Gravity interpretation of the western flank of the Brabant Massif. Koninklijk Meteorologisch Instituut van België, Publicaties, Serie A/ Institut Royal Métérologique de Belgique, Publications, Série A, 111, 1-50.

DE Vos, W. 1997. Influence of the granitic batholith of Flanders on Acadian and later deformation (Brabant Massif, Belgium). Aardkundige Mededelingen, 8, $49-52$.

De Vos, W., Poot, B., Hus, J. \& El Khayati, M. 1992. Geophysical characterization of lithologies from the Brabant Massif as a contribution to gravimetric and magnetic modelling. Bulletin de la Société Belge de 
Géologie, 101, 173-180.

De Vos, W., Chacksfield, B.C. \& D'hooge, L. et aL. 1993a. Image-based display of Belgian digital aeromagnetic and gravity data. Professional Papers of the Geological Survey of Belgium, 263, 1-8.

De Vos, W., Verniers, J., Herbosch, A. \& Vanguestaine, M. 1993b. A new geological map of the Brabant Massif, Belgium. Geological Magazine, 130, 605-611.

Dewey, J.F., Holdsworth, R.E. \& Strachan, R.A. 1998. Transpression and transtension zones. In: Holdsworth, R.E., Strachan, R.A. \& Dewey, J.F. (eds) Continental Transpressional and Transtensional Tectonics. Geological Society, London, Special Publications, 135, 1-14.

Everaerts, M., Poitevin, C., De Vos, W. \& Sterpin, M. 1996. Integrated geophysical/geological modelling of the western Brabant Massif and structural implications. Bulletin de la Société Belge de Géologie, 105, 41-59.

Fleuty, M.J. 1964. The description of folds. Proceedings of the Geological Association, London, 75, 461-492.

Fossen, H. \& Rykkelid, E. 1990. Shear zone structures in the Oygarden area, West Norway. Tectonophysics, 174, 385-397.

Fossen, H. \& Tikoff, B. 1993. The deformation matrix for simultaneous simple shearing, pure shearing and volume change, and its application to transpression-transtension tectonics. Journal of Structural Geology, 15, 413-422.

Fourmarier, P. 1914. La poussée calédonienne dans le massif siluro-cambrien du Brabant. Annales de la Société Géologique de Belgique, 41, B300-B314.

Fourmarier, P. 1921. La tectonique du Brabant et des régions voisines. Mémoires de l'Académie Royale de Belgique, Classe des Sciences, 2ème Série, 4, 1-95.

HaRLand, W.B. 1971. Tectonic transpression in Caledonian Spitsbergen. Geological Magazine, 108, 27-42.

HoLDSWORTH, R.E. 1989. The Start-Perranporth line: a Devonian terrane boundary in the Variscan orogen of SW England? Journal of the Geological Society, London, 146, 419-421.

Holdsworth, R.E. \& Pinheiro, R.V.L. 2000. The anatomy of shallow-crustal transpressional structures: insights from the Archaean Carajas fault zone, Amazon, Brazil. Journal of Structural Geology, 22, 1105-1123.

Holdsworth, R.E., Tavarnelli, E. \& ClegG, P. 2002a. The nature and regional significance of structures in the Gala Group of the Southern Uplands terrane, Berwickshire coast, southeastern Scotland. Geological Magazine, 139, 707-717.

Holdsworth, R.E., Tavarnelli, E., Clegg, P., Pinheiro, R.V.L., Jones, R.R. \& McCAFFREY, K.J.W. 2002b. Domainal deformation patterns and strain partitioning during transpression: examples from the Southern Uplands terrane, Scotland. Journal of the Geological Society, London, 159, 401-415.

Johnson, T.E. 1991. Nomenclature and geometric classification of cleavagetransected folds. Journal of Structural Geology, 13, 261-274.

Jones, L. 1948. Le levé gravimétrique de la Belgique. Bulletin de la Société Belge de Géologie, de Paléontologie et d'Hydrologie, 57, 568-575.

JoNES, R.R. \& TANNER, G.P.W. 1995. Strain partitioning in transpression zones. Journal of Structural Geology, 17, 793-802.

Jones, R.R., Holdsworth, R.E. \& Bailey, W. 1997. Lateral extrusion in transpression zones: the importance of boundary conditions. Journal of Structural Geology, 19, 1201-1217.

Lee, M.K., Pharaoh, T.C., Williamson, J.P., Green, C.A. \& De Vos, W. 1993. Evidence of the deep structure of the Anglo-Brabant Massif from gravity and magnetic data. Geological Magazine, 130, 575-582.

Legrand, R. 1967. Ronquières, documents géologiques. Mémoires pour servir à l'Explication des Cartes Géologiques et Minières de la Belgique, $\mathbf{6}$.

Legros, B. 1991. Etude structurale du Cambro-Ordovicien de la vallée de la Sennette (Massif du Brabant)—Belgique. MSc thesis, Université Catholique de Louvain.

LENOIR, J.L. 1987. Etude cartographique, pétrographique et palynologique de l'Ordovicien inférieur du bassin de la Senne. MSc thesis, Université Libre de Bruxelles.

Malaise, C. 1873. Description du terrain silurien du centre de la Belgique. Mémoires Couronnés de l'Académie Royale de la Belgique, Classe des Sciences, 37, 1-122.

Mansy, J.L., Everaerts, M. \& De Vos, W. 1999. Structural analysis of the adjacent Acadian and Variscan fold belt in Belgium and northern France from geophysical and geological evidence. Tectonophysics, 309, 99-116.

MIES, J.W. 1993. Structural analysis of sheath folds in the Sylacauga Marble Group, Talladega slate belt, southern Appalachians. Journal of Structural Geology, 15, 983-993.

Mortelmans, G. 1953. Efforts calédoniens et efforts hercyniens dans le silurien de la vallée de l'Orneau. Bulletin de la Société Belge de Géologie, de Paléontologie et d'Hydrologie, 62, 143-164.

PARK, A.F. 1988. Geometry of sheath folds and related fabrics at the Luikonlahti mine, Svecokarelides, eastern Finland. Journal of Structural Geology, 10, 487-498.

RAMSAY, J.G. 1958. Superimposed folding at Loch Monar, Inverness-shire and Ross-shire. Quarterly Journal of the Geological Society of London, 113, 271-308.

RAMSAY, J.G. 1962. Interference patterns produced by the superposition of folds of similar types. Journal of Geology, 70, 466-481.

Ramsay, J.G. \& Graham, R.H. 1970. Strain variation in shear belts. Canadian Journal of Earth Sciences, 7, 786-813.

Ramsay, J.G. \& Huber, M.I. 1983. The Techniques of Modern Structural Geology, Volume 1: Strain Analysis. Academic Press, London.

REynoldS, D.L. \& Holmes, A. 1954. The superposition of Caledonoid folds on an older fold system in the Dalradians of Malin Head, Co. Donegal. Geological Magazine, 91, 417-433.

SANDERSON, D.J. \& MarchinI, W.R.D. 1984. Transpression. Journal of Structural Geology, 6, 449-458.

Sintubin, M. 1994. Textures in shales and slates. In: Bunge, H.J., Siegensmund, S., Strotski, W. \& Weber, K. (eds) Textures of Geological Materials. DGM Informationsgesellschaft Verlag, Town, 221-229.

Sintubin, M. 1997a. Cleavage-fold relationships in the Lower Palaeozoic Brabant Massif (Belgium). Aardkundige Mededelingen, 8, 161-164.

Sintubin, M. 1997b. Structural implications of the aeromagnetic lineament geometry in the Lower Palaeozoic Brabant Massif (Belgium). Aardkundige Mededelingen, $\mathbf{8}, 165-168$.

SinTuBin, M. 1999. Arcuate fold and cleavage patterns in the southeastern part of the Anglo-Brabant fold belt (Belgium): tectonic implications. Tectonophysics, 309, 81-97.

Sintubin, M. \& EveraerTs, M. 2002. A compressional wedge model for the Lower Palaeozoic Anglo-Brabant Belt (Belgium) based on potential field data. In: Winchester, J., Verniers, J. \& Pharaoh, T. (eds) Palaeozoic Amalgamation of Central Europe. Geological Society, London, Special Publications, 201, 327-343.

Sintubin, M., Brodkom, F. \& Laduron, D. 1998. Cleavage/fold relationships in the Lower Cambrian Tubize Group, southeast Anglo-Brabant fold belt (Lembeek, Belgium). Geological Magazine, 135, 217-226.

SkJernaA, L. 1989. Tubular folds and sheath folds: definitions and conceptual models for their development, with examples from the Grapesvare area, northern Sweden. Journal of Structural Geology, 11, 689-703.

Soper, N.J. \& Hutton, D.H.W. 1984. Late Caledonian sinistral displacements in Britain: implications for a three-plate collision model. Tectonics, 3, 781-794.

Soper, N.J., Strachan, R.A., Holdsworth, R.E., Gayer, R.A. \& Greiling, R.O. 1992. Sinistral transpression and the Silurian closure of Iapetus. Journal of the Geological Society, London, 149, 871-880.

Tikoff, B. \& Greene, D. 1997. Stretching lineations in transpressional shear zones: an example from the Sierra Nevada Batholith, California. Journal of Structural Geology, 19, 29.

VANDER AuWERA, J. 1983. Étude pétrographique, sédimentologique et géochimique de l'Assise de Tubize (DV2)—Massif du Brabant_Belgique. MSc thesis, Université Libre de Bruxelles.

Vander Aumera, J. \& André, L. 1985. Sur le milieu de dépôt, l'origine des matériaux et le faciès métamorphique de l'Assise de Tubize (Massif du Brabant, Belgique). Bulletin de la Société Belge de Géologie, 94, 171-184.

Van Grootel, G., Verniers, J., Geerkens, B., Laduron, D., Verhaeren, M., Hertogen, J. \& De Vos, W. 1997. Timing of subsidence-related magmatism, foreland basin development, metamorphism and inversion in the AngloBrabant fold belt. Geological Magazine, 134, 607-616.

Van Grootel, G., Verniers, J. \& Debacker, T.N. 2002. Overview of the Upper Ordovician of the Fauquez area (Brabant Massif, Belgium), lithostratigraphy, biostratigraphy, geological map and structures. Aardkundige Mededelingen, $12,77-79$.

Verniers, J., Herbosch, A. \& Vanguestaine, M. et al. 2001. CambrianOrdovician-Silurian lithostratigraphical units (Belgium). Geologica Belgica, 4, 5-38.

Verniers, J., Pharaoh, T. \& André, L. et al. 2002. Lower Palaeozoic basin development and Caledonian deformation history in and around Belgium in the framework of Eastern Avalonia. In: Winchester, J., Verniers, J. \& Pharaoh, T. (eds) Palaeozoic Amalgamation of Central Europe. Geological Society, London, Special Publications, 201, 47-93. 